\title{
Anteroposterior Orientation
}

National Cancer Institute

\section{Source}

National Cancer Institute. Anteroposterior Orientation. NCI Thesaurus. Code C85512.

Directed from front to back. 